\title{
Lapatinib for treatment of advanced or metastasized breast cancer: systematic review
}

\section{Lapatinib no tratamento do câncer de mama avançado ou metastático: revisão sistemática}

\author{
Rachel Riera', Patrícia Coelho de Soárez", Maria Eduarda dos Santos Puga"', Marcos Bosi Ferraz ${ }^{\text {IN }}$ \\ Centro Paulista de Economia da Saúde (CPES), Universidade Federal de São Paulo (Unifesp), São Paulo, Brazil
}

\section{KEY WORDS:}

Breast neoplasms.

Review.

Antineoplastic agents. Antineoplastic protocols. Receptor, erbB-2.

\section{PALAVRAS-CHAVE:}

Neoplasias de mama.

\section{Revisão.}

Antineoplásicos.

Protocolos antineoplásicos.

Receptor erbB-2.

\begin{abstract}
CONTEXT AND OBJECTIVE: Around $16 \%$ to $20 \%$ of women with breast cancer have advanced, metastasized breast cancer. At this stage, the disease is treatable, but not curable. The objective here was to assess the effectiveness of lapatinib for treating patients with advanced or metastasized breast cancer.

DESIGN AND SETtING: Systematic review of the literature, developed at Centro Paulista de Economia da Saúde (CPES), Universidade Federal de São Paulo (Unifesp).

METHOD: Systematic review with searches in virtual databases (PubMed, Lilacs [Literatura Latino-Americana e do Caribe em Ciências da Saúde], Cochrane Library, Scirus and Web of Science) and manual search.

RESULTS: Only one clinical trial that met the selection criteria was found. This study showed that lapatinib in association with capecitabine reduced the risk of cancer progression by $51 \%$ (95\% confidence interval, $\mathrm{Cl}: 0.34-0.71 ; \mathrm{P}<0.001)$, compared with capecitabine alone, without any increase in severe adverse effects.

CONCLUSION: The combination of lapatinib plus capecitabine was more effective than capecitabine alone for reducing the risk of cancer progression. Further randomized clinical trials need to be carried out with the aim of assessing the effectiveness of lapatinib as monotherapy or in association for first-line or second-line treatment of advanced breast cancer.
\end{abstract}

\section{RESUMO}

CONTEXTO E OBJETIVO: Aproximadamente $16 \%$ a $20 \%$ das mulheres com câncer de mama têm doença avançada com metástases. Neste estágio, a doença é tratável, porém incurável. 0 objetivo foi avaliar a efetividade do lapatinib no tratamento de pacientes com câncer de mama avançado ou metastático.

TIPO DE ESTUDO E LOCAL: Revisão sistemática da literatura desenvolvida no Centro Paulista de Economia da Saúde (CPES), Universidade Federal de São Paulo (Unifesp).

MÉTOD0: Revisão sistemática com busca em bases de dados virtuais (PubMed, Lilacs [Literatura Latino-Americana e do Caribe em Ciências da Saúde], Cochrane Library, Scirus and Web of Science) e busca manual.

RESULTADOS: Foi encontrado apenas um ensaio clínico que preencheu os critérios de seleção. Este estudo mostrou que o lapatinib em associação com a capecitabina reduziu em $51 \%$ o risco de progressão da doença (intervalo de confiança, IC 95\%: 0,34-0,71; P < 0,001) quando comparado com a capecitabina isolada, sem aumento de efeitos adversos graves.

CONCLUSÃO: A combinação de lapatinib e capecitabina foi mais efetiva do que a capecitabina isolada na redução do risco de progressão da doença. Ensaios clínicos aleatórios devem ser realizados com o objetivo de avaliar a efetividade do lapatinib como monoterapia ou em associação no tratamento primário ou secundário do câncer de mama avançado.

IMD, MSc. Physician and research assistant at Centro Paulista de Economia da Saúde (CPES), Universidade Federal de São Paulo (Unifesp), São Paulo, Brazil. "MSc. Dental surgeon, professor and researcher at Centro Paulista de Economia da Saúde (CPES), Universidade Federal de São Paulo (Unifesp), São Paulo, Brazil. "'MSC. Librarian and research assistant at Centro Paulista de Economia da Saúde (CPES), Universidade Federal de São Paulo (Unifesp), São Paulo, Brazil. IMD, MSc, PhD. Physician and Director of Centro Paulista de Economia da Saúde (CPES), Universidade Federal de São Paulo (Unifesp), São Paulo, Brazil. 


\section{INTRODUCTION}

Breast cancer is the most common type of cancer found in women and is the main cause of cancer deaths among women. ${ }^{1}$ In 2000, more than one million new cases of breast cancer were reported, and approximately 373,000 deaths worldwide were attributed to this. ${ }^{1}$

While many cases of breast cancer in the early stages are successfully treated, it is considered incurable when there is recurrence of the disease with metastasis. Nevertheless, such situations are treatable. ${ }^{2}$

Advanced or metastasized breast cancer is defined as a clinical stage that corresponds to phases III and IV of the cancer, based on the tumor itself, lymph node involvement and metastases. ${ }^{3}$

Approximately $16 \%$ to $20 \%$ of women with breast cancer have advanced, metastasized breast cancer, and $50 \%$ of early-stage breast cancer ultimately develops to metastasized breast cancer. ${ }^{4}$ Some women with metastasized breast cancer live for many years, but the average survival upon diagnosis ranges from 18 to 24 months. ${ }^{3,5}$ Women with advanced or metastasized breast cancer that overexpresses epidermal growth factor receptors (EGFR) have a worse prognosis, with a high risk of recurrence after the primary treatment and a 50\% reduction in mean survival.4-6

The treatment objective in cases of advanced or metastasized breast cancer is to control the symptoms and prolong life, given that such cases are considered incurable and that first-line surgery will have been ineffective. ${ }^{3-7}$ Although there is no evidence from randomized studies comparing chemotherapy with observation alone, among women with this type of breast cancer, it is widely accepted that these patients should receive some type of systematic treatment at some point during the illness. ${ }^{8}$

In advanced cases, the therapies usually include prescription of anthracycline or a combination of cyclophosphamide, methotrexate and fluorouracil. ${ }^{9,10}$ The guidelines published by the National Institute for Health and Clinical Excellence (NICE) also include capecitabine, vinorelbine, docetaxel, paclitaxel, gemcitabine and trastuzumab., ${ }^{41-14}$

Considering that women with breast cancer with overexpression of EGFR are at greater risk of cancer progression, therapeutic strategies have been developed to block the activity of these receptors and to improve the response to treatment. ${ }^{15,16}$

The EGFR family includes four subtypes: HER-1 (human epidermal receptor), HER-2, HER-3 and HER-4. ${ }^{17-19}$ Overexpression of HER-1 occurs in approximately $27 \%-30 \%$ of breast cancer cases, while overexpression of HER-2 is recorded in $20 \%-25 \%$ of the 1.5 million new breast cancer cases diagnosed annually worldwide. ${ }^{17,18}$

These receptors do not stay put in a given spot on the cell membrane, and the extracellular domains of pairs of receptors attach to each other via a connection that forms a dimer. These dimers may be homodimers (i.e. two identical receptors, such as HER-1 and HER-1, etc.) or heterodimers (i.e. different receptors, such as HER-1 and HER-2, etc.). ${ }^{17-21}$ After dimerization, the intracellular tyrosine kinase domain is activated, thus stimulating cell proliferation. ${ }^{17}$

Lapatinib (GW572016/Tykerb; GlaxoSmithKline, Research Triangle Park, North Carolina, United States) is an oral inhibitor of HER-1 and HER-2 receptors that attaches to the intracellular tyrosine kinase domain, thereby blocking the growth of tumor cells. ${ }^{17,22}$ It presents some theoretical advantages over monoclonal antibodies that block the intracellular domain of the HER-2 receptor (e.g. trastuzumab, Herceptin; Genentech, Inc., South San Francisco, California, United States). ${ }^{6}$

Inhibition of a single receptor subtype cannot be as effective as double inhibition of the heterodimers containing HER-1 and HER-2. ${ }^{23}$ Moreover, there are truncated receptors that do not have extracellular domains and that are not recognized by the antibodies that connect to this domain. In fact, a truncated form of HER-2 known as p95 that has much more tyrosine kinase activity than other forms of HER-2 has been documented. ${ }^{6}$

Lapatinib has been effective in inhibiting p95HER-2 phosphorylation in BT474 cells and in tumor xenografts. On the other hand, trastuzumab does not bind to or inhibit the p95HER-2 receptor, which suggests that resistance to trastuzumab can be measured through the overexpression of p95HER-2 receptors during cancer progression. ${ }^{24}$ Overexpression of p95HER-2 receptors has also been observed as an independent prognostic factor for breast cancer cases, thus defining a group of patients with increased expression of HER-2 that demonstrates a shorter cancer-free survival period. ${ }^{25}$ In practice, in cases of metastasis, resistance to trastuzumab occasionally develops, in addition to recurrence after adjuvant therapy. ${ }^{26-30}$

Given the theoretical benefits of lapatinib, taking into account the prevalence of this type of cancer and the difficulty in managing it, a systematic review is necessary in order to map out the evidence available, prove the effectiveness of this medication and, thus, provide support for its use in treating advanced or metastasized breast cancer.

\section{OBJECTIVE}

To assess the effectiveness of lapatinib as monotherapy or in association with another drug during first-line or second-line treatment of patients with advanced or metastasized breast cancer.

\section{MATERIAL AND METHODS}

\section{Search strategy}

A systematic review of the literature was conducted from the following sources: a) virtual search: Cochrane Library, PubMed, Embase, Lilacs (Literatura Latino-Americana e do Caribe em Ciências da Saúde), Web of Science and Scirus; b) manual search: search of the references listed in articles and congress abstracts, contacts with authors and contacts with the pharmaceutical industry. The search strategy used for each virtual database is available in Table 1.

\section{Study selection criteria}

The criteria for study selection were that they should be randomized clinical trials assessing the effectiveness of lapatinib as monotherapy or in association with another drug, compared with placebo or another intervention or treatment for women with advanced or metastasized breast cancer, as a first-line or second-line treatment.

All abstracts from the 689 articles that were found were evaluated to select the likely clinical studies of interest. When in doubt, the article was evaluated in its entirety. 


\section{Assessment of study methodological quality}

The following evaluation scales were used: a) Jadad, ranging from 0 to 5 , in which higher ratings signified better methodological quality of implementation of the study; and b) the Cochrane Collaboration Handbook. ${ }^{31,32}$

\section{RESULTS}

Three papers were selected, which each reported on a single randomized clinical trial that met the selection criteria. ${ }^{16,33,34}$ The same papers were found in more than one database as well as in the manual search. No randomized clinical trials that evaluated the effectiveness of lapatinib as monotherapy for first-line or second-line treatment of advanced or metastasized breast cancer were found. Nor were any randomized clinical trials assessing the effectiveness of lapatinib in association with another drug for first-line treatment for metastasized breast cancer found. The search strategy and its results are contained in Table 1.

The clinical trial included in the systematic review evaluated 324 women with advanced breast cancer with HER-2 receptors (T4 primary tumor and stage IIIB or IIIC) or with metastasized cancer that had progressed subsequent to first-line treatment with anthracycline, taxane and trastuzumab. ${ }^{16}$ The cancer was evaluated according to the Response Evaluation Criteria in Solid Tumors (RECIST), modified to include le- sions measuring 15 to $19 \mathrm{~mm}$, with the ventricular ejection fraction within normal range as established by the institution and with the renal, hepatic and hematological systems functioning properly. Women with previous heart conditions, illnesses that could interrupt gastrointestinal absorption and patients who had ever received capecitabine as monotherapy before the beginning of this study were excluded. One group $(\mathrm{n}=161)$ received capecitabine $2500 \mathrm{mg} / \mathrm{m}^{2} /$ day orally on days 1 and 14 in a 21-day cycle and the other group $(\mathrm{n}=163)$ received capecitabine $2000 \mathrm{mg} / \mathrm{m}^{2} /$ day orally on days 1 and 14 every 3 weeks and lapatinib $1250 \mathrm{mg} /$ day orally, continuously. The randomization was implemented in groups of six patients and, for the groups to be homogenous and comparable, they were stratified according to the cancer stage and the presence or absence of visceral disease.

The primary outcome was the "progression time", defined as the length of time between randomization and the occurrence of disease progression or death due to breast cancer. The secondary outcomes were: length of survival free from disease progression (the length of time between randomization and disease progression or death from any cause), the total response rate, the clinical benefit rate (full or partial response or stabilization of the disease for at least six months) and safety. The patients were evaluated every six weeks over the first 24 weeks and, subsequently, every 12 weeks over the duration of the treatment. Intention to treat (effectiveness) analysis was carried out.

Table 1. Search strategies and results

\begin{tabular}{|c|c|c|c|}
\hline Source & Search strategy & Number & RCT criteria selection \\
\hline Cochrane Library & (lapatinib or tykerb or gw572016 or gw282974x or lapatinib and ditosylate) & 16 & 1 \\
\hline PubMed & $\begin{array}{l}\text { \#1 (“lapatinib “[Substance Name]) OR (lapatinib) OR (GW 282974X) OR (GW-282974X) OR (GW282974X) OR } \\
\text { (GW572016) OR (GW 572016) OR (GW-572016) OR (lapatinib ditosylate) OR (N-(3-chloro-4-(((3-fluorobenzyl)oxy) } \\
\text { phenyl)-6-(5-(((2-methylsulfonyl)ethyl)amino)methyl) -2-furyl)-4-quinazolinamine) OR (Tykerb) } \\
\text { \#2 (“Breast Neoplasms”[Mesh]) OR (Breast Neoplasm*) OR (Neoplasm, Breast) OR (Breast Tumors) OR (Breast Tumor) OR } \\
\text { (Tumor, Breast) OR (Neoplasms, Breast) OR (Tumors, Breast) OR (Breast Cancer) OR (Cancer, Breast) OR (Cancer of Breast) } \\
\text { OR (Cancer of the Breast) OR (Mammary Carcinoma, Human) OR (Carcinoma, Human Mammary) OR (Carcinomas, Human } \\
\text { Mammary) OR (Human Mammary Carcinomas) OR (Mammary Carcinomas, Human) OR (Human Mammary Carcinoma) } \\
\text { OR (Mammary Neoplasms, Human) OR (Human Mammary Neoplasm) OR (Human Mammary Neoplasms) OR (Neoplasm, } \\
\text { Human Mammary) OR (Neoplasms, Human Mammary) OR (Mammary Neoplasm, Human) } \\
\text { \#3 (\#1) AND (\#2) }\end{array}$ & 157 & 1 \\
\hline EMBASE & $\begin{array}{l}\text { Search: 'lapatinib'/exp AND 'breast cancer'/exp AND [embase]/lim. Mapped terms: 'lapatinib' mapped to ‘lapatinib', term } \\
\text { is exploded } \\
\text { 'breast cancer' mapped to 'breast cancer', term is exploded } \\
\text { Limited to: embase } \\
\text { Period: All Publication Years }\end{array}$ & 424 & 1 \\
\hline Lilacs & $\begin{array}{l}\text { (“lapatinib “[Substance Name]) OR (lapatinib) OR (GW 282974X) OR (GW-282974X) OR (GW282974X) OR (GW572016) } \\
\text { OR (GW 572016) OR (GW-572016) OR (lapatinib ditosylate) OR (N-(3-chloro-4-(((3-fluorobenzyl)oxy)phenyl)-6-(5-(((2- } \\
\text { methylsulfonyl)ethyl)amino)methyl) -2-furyl)-4-quinazolinamine) OR (Tykerb) [Palavras] }\end{array}$ & 0 & 0 \\
\hline SCIRUS & ((lapatinib) OR (GW572016) OR (GW 572016) OR (Tykerb)) AND (breast neoplasm) & 23 & 1 \\
\hline Web of Science & $\begin{array}{l}\text { \#1 TS=(lapatinib) DocType=All document types; Language=All languages; Database=SCI-EXPANDED; Timespan=1945-2007 } \\
\text { \#2 TS=(tyberk) DocType=All document types; Language=All languages; Database=SCI-EXPANDED; Timespan=1945-2007 } \\
\text { \#3 TS=tykerb DocType=All document types; Language=All languages; Database=SCI-EXPANDED; Timespan=1945-2007 } \\
\text { \#4 TS=Iapatinib ditosylate DocType=All document types; Language=All languages; Database=SCI-EXPANDED; } \\
\text { Timespan=1945-2007 } \\
\text { \#5 TS=GW 572016 DocType=All document types; Language=All languages; Database=SCI-EXPANDED; Timespan=1945- } \\
2007 \\
\text { \#6 TS=breast Neoplasm DocType=All document types; Language=All languages; Database=SCI-EXPANDED; } \\
\text { Timespan=1945-2007 } \\
\text { \#7\#5 OR \#4 OR \#3 OR \#1DocType=All document types; Language=All languages; Database=SCI-EXPANDED; } \\
\text { Timespan=1945-2007 } \\
\text { \#8 \#7 AND \#6DocType=All document types; Language=All languages; Database=SCI-EXPANDED; Timespan=1945-2007 }\end{array}$ & 2 & 0 \\
\hline Manual Search & -- & 67 & 3 \\
\hline Total & & 689 & $7^{*}$ \\
\hline
\end{tabular}

* There were overlaps in the references, resulting in a total of three papers, which actually reported the data from the same clinical study. Of these papers, one was an original article, and the others were congress abstracts published in journal supplements. RCT = randomized clinical trial. 
Table 2. Outcomes from intention-to-treat (effectiveness) analysis ${ }^{16}$

\begin{tabular}{|c|c|c|c|c|}
\hline Outcomes & $\begin{array}{l}\text { Lapatinib + capecitabine } \\
\qquad(n=163)\end{array}$ & $\begin{array}{c}\text { Capecitabine alone } \\
(n=161)\end{array}$ & $\begin{array}{l}\text { Risk ratio } \\
(95 \% \mathrm{Cl})\end{array}$ & P-value \\
\hline Average length of time until disease progression (months) & 8.4 & 4.4 & $0.49(0.34-0.71)$ & $<0.001^{*}$ \\
\hline Average length of survival free from disease progression (months) & 8.4 & 4.1 & $0.47(0.33-0.67)$ & $<0.001^{*}$ \\
\hline Total response rate $\%(95 \% \mathrm{Cl})$ & $22(16-29)$ & $14(9-21)$ & - & $0.09+$ \\
\hline Full response $\mathrm{n}(\%)$ & $1(<1)$ & $0(0)$ & - & - \\
\hline Partial response $\mathrm{n}(\%)$ & $35(21)$ & $23(14)$ & - & - \\
\hline Patients with clinical benefit $n(\%)$ & $44(27)$ & $29(18)$ & - & - \\
\hline Deaths n (\%) & $36(22)$ & $35(22)$ & - & - \\
\hline
\end{tabular}

$\mathrm{Cl}=$ confidence interval. ${ }^{*}$ log-rank test; ${ }^{\dagger}$ Fisher's exact test.

Compared with capecitabine alone, the association of lapatinib and capecitabine doubled the average length of time until disease progression, which was 8.4 months for the latter and 4.4 months for the group treated solely with capecitabine (hazard ratio $=0.49 ; 95 \%$ confidence interval, CI: 0.34-0.71; P < 0.001). In other words, the combined treatment reduced the risk of breast cancer progression by $50 \%$, in relation to treatment solely with capecitabine. An increase in the length of time until disease progression was observed for all patients in the group that received the combined treatment. The secondary outcomes are shown in Table 2.

Four patients in the combined therapy group developed cerebral metastasis as the first progression site, compared with 11 patients in the group treated solely with capecitabine $(P=0.10)$. The frequency of adverse effects was similar in the two groups, with the exception of diarrhea, which occurred more frequently in the combined-treatment group $(\mathrm{P}<0.001)$. The treatment discontinuation rate due to side effects was $13 \%$ in the combined-therapy group and $12 \%$ in the group treated solely with capecitabine. The most common adverse effects in both groups were diarrhea, hand-foot syndrome, nausea, vomiting, fatigue and rash. Asymptomatic reduction of the left ventricular ejection fraction $\geq 20 \%$ was observed in four patients in the combined-treatment group and in one patient in the single-treatment group, but there were no symptomatic cardiac events or cases of discontinuation of the treatment due primarily to cardiac function.

\section{DISCUSSION}

Considering that only one clinical trial evaluating the effectiveness of lapatinib for treating advanced or metastasized breast cancer was found and selected, and considering that this study only dealt with the use of lapatinib for second-line treatment and in association with capecitabine, there are limitations on the results from this systematic review, despite their relevance.

With regard to methodological evaluation, the study that was reviewed was given a rating of $\mathrm{B}$ on the scale set out in the Cochrane Collaboration Handbook and a rating of 3 on the Jadad scale, since it demonstrated an adequate randomization technique, was double blind and described losses and exclusions. ${ }^{31,32}$ Nevertheless, the study presented a risk of breakage of the allocation concealment, since the method through which the treatments were administered was not considered identical between the two groups. This was because of a lack of reporting on whether the group treated solely with capecitabine also continuously received placebo. The foregoing results allowed us to classify the study as having moderate risk of bias. ${ }^{31,32}$ According to the level-of-evidence classification established by the Oxford Centre for EvidenceBased Medicine, the results from this clinical study support the use of lapatinib in association with capecitabine, at the doses prescribed and for this specific group of patients with advanced or metastasized breast cancer, with a level of evidence of $1 \mathrm{~b}$ and a grade of recommendation of A. ${ }^{35}$ The study was financed and conducted by GlaxoSmithKline.

The published results from this trial correspond to an internal analysis $(n=324)$ on a study that intended to include 528 patients (statistical power $=90 \%, \alpha=0.05)$ and which was conducted after 114 instances of cancer progression. Since this analysis demonstrated that the addition of lapatinib to capecitabine was associated with a reduction in the risk of disease progression by $51 \%$, the safety monitoring committee recommended that the study should be closed and that a report containing this information should be drafted.

Based on updated data from this study, in March 2007 the Swiss government and the United States (US) Food and Drug Administration (FDA) approved the use of lapatinib in combination with capecitabine for treatment of metastasized or advanced breast cancer with HER-2 receptors, for patients who had received anthracycline, taxane and trastuzumab as first-line treatment. ${ }^{30,36}$ The updated results demonstrated that there was a significant increase in the average length of time until cancer progression in the combined-treatment group, from 18.6 to 27.1 weeks $(\mathrm{HR}=0.57 ; 95 \%$ CI 95\%: 0.43-0.77; $\mathrm{P}=0.00013) .{ }^{36}$ The total response rate also remained high in the combined-treatment group: $24 \%$ (95\% CI: 18\%-30.3\%) versus 14\% (95\% CI: 9.5\%-19.5\%). ${ }^{36}$

No randomized clinical trials evaluating the effectiveness of lapatinib in any of the following situations were found: a) as the sole firstline or second-line treatment for advanced or metastasized breast cancer; b) as part of a combined treatment for the first-line or secondline treatment of advanced or metastasized breast cancer; c) as part of a combined treatment for first-line treatment of advanced or metastasized breast cancer; or d) as part of a combined treatment with a drug other than capecitabine for second-line treatment of advanced or metastasized breast cancer. Therefore, Table 3 includes data from phase II and III clinical studies that have already been implemented or are in progress, with objectives that fit within the foregoing list. ${ }^{37-53}$

\section{CONCLUSIONS}

The combination of lapatinib and capecitabine was more effective than capecitabine alone for reducing the risk of cancer progression in 
Table 3. Phase II and III studies on lapatinib for treatment of advanced or metastasized cancer

\begin{tabular}{|c|c|c|c|c|c|c|c|}
\hline Study & Intervention & Phase & Primary outcome & Full response (\%) & Partial response (\%) & Stabilized disease (\%) & IPT (months) \\
\hline \multicolumn{8}{|l|}{ First-line treatment } \\
\hline EGF20009 ${ }^{37}$ & $\begin{array}{l}\text { lapatinib } \\
1 \text { dose/day versus } \\
2 \text { doses/day }\end{array}$ & II & GRR & 0 & 35 & 35 & NR \\
\hline EGF30001 ${ }^{38}$ & $\begin{array}{l}\text { paclitaxel/lapatinib versus } \\
\text { paclitaxel/placebo }\end{array}$ & III & $\begin{array}{l}\text { IPT, GRR survival } \\
\text { biomarker }\end{array}$ & \multicolumn{4}{|c|}{ In progress } \\
\hline EGF104383 ${ }^{39}$ & $\begin{array}{l}\text { paclitaxel/trastuzumab/ } \\
\text { lapatinib versus paclitaxel/ } \\
\text { trastuzumab/placebo }\end{array}$ & III & $\begin{array}{l}\text { IPT, GRR survival } \\
\text { biomarker }\end{array}$ & \multicolumn{4}{|c|}{ in progress } \\
\hline EGF30008 ${ }^{40}$ & $\begin{array}{l}\text { letrozole/lapatinib versus } \\
\text { letrozole/placebo }\end{array}$ & III & $\begin{array}{l}\text { IPT, GRR survival } \\
\text { biomarker }\end{array}$ & \multicolumn{4}{|c|}{ in progress } \\
\hline EGF10435341 & $\begin{array}{l}\text { paclitaxel/lapatinib versus } \\
\text { paclitaxel/placebo }\end{array}$ & III & $\begin{array}{l}\text { IPT, GRR survival } \\
\text { biomarker }\end{array}$ & \multicolumn{4}{|c|}{ in progress } \\
\hline \multicolumn{8}{|c|}{ (Refractory) second-line or third-line treatment } \\
\hline EGF20002 $2^{42,43}$ & Lapatinib & II & GRR safety & $8^{*}$ & - & 14 & $22 \%^{\dagger}$ \\
\hline EGF20008 43,44 & \multirow[t]{3}{*}{ Lapatinib } & \multirow[t]{3}{*}{$\|$} & \multirow[t]{3}{*}{ GRR safety } & & & & \multirow{3}{*}{$13 \%^{\dagger}$} \\
\hline cohort A (HER-2 +) & & & & $4^{*}$ & - & $9^{+}$ & \\
\hline cohort B (HER-2 -) & & & & $0 *$ & - & 1 & \\
\hline EGF10490045 & $\begin{array}{l}\text { trastuzumab/lapatinib versus } \\
\text { lapatinib }\end{array}$ & III & $\begin{array}{l}\text { GRR } \\
\text { SFP }\end{array}$ & \multicolumn{4}{|c|}{ in progress } \\
\hline EGF10508446 & lapatinib (cerebral metastasis) & $\|$ & GRR & \multicolumn{4}{|c|}{$16.3 \%$ of the patients show a $20 \%$ volume reduction in the cerebral lesion } \\
\hline NCI-CTEP $6969{ }^{47}$ & lapatinib (cerebral metastasis) & II & GRR in the CNS & 0 & $5^{\ddagger}$ & NR & 3.2 \\
\hline \multicolumn{8}{|c|}{ Inflammatory breast cancer } \\
\hline EGF10390048 & \multirow[t]{3}{*}{ Lapatinib } & \multirow[t]{3}{*}{ II } & \multirow[t]{3}{*}{ GRR } & & & & \multirow[t]{3}{*}{ NR } \\
\hline cohort A & & & & 0 & 62 & 21 & \\
\hline cohort B & & & & 0 & 8 & 17 & \\
\hline EGF10258049 & $\begin{array}{l}\text { Lapatinib + paclitaxel versus } \\
\text { (neoadjuvant) }\end{array}$ & $\|$ & NR & & in progr & & \\
\hline \multicolumn{8}{|l|}{ Adjuvant treatment } \\
\hline ALTTO50 & $\begin{array}{l}\text { trastuzumab one year versus } \\
\text { lapatinib one year versus } \\
\text { trastuzumab/lapatinib one year } \\
\text { versus trastuzumab } \\
\text { three months } \rightarrow \text { lapatinib nine } \\
\text { months }\end{array}$ & III & $\begin{array}{l}\text { survival } \\
\text { IPT, GRR } \\
\text { safety }\end{array}$ & \multicolumn{4}{|c|}{ in progress } \\
\hline TEACH $^{51,52}$ & $\begin{array}{l}\text { lapatinib one year versus } \\
\text { placebo }\end{array}$ & III & $\begin{array}{l}\text { survival } \\
\text { SFI, QOL } \\
\text { recurrence CNS }\end{array}$ & \multicolumn{4}{|c|}{ in progress } \\
\hline \multicolumn{8}{|c|}{ Neoadjuvant treatment } \\
\hline NeoALTTO ${ }^{53}$ & $\begin{array}{l}\text { lapatinib/paclitaxel versus } \\
\text { trastuzumab/paclitaxel versus } \\
\text { lapatinib/trastuzumab/ } \\
\text { paclitaxel }\end{array}$ & III & $\begin{array}{l}\text { GRR, IPT } \\
\text { safety } \\
\text { tolerability } \\
\text { survival }\end{array}$ & \multicolumn{4}{|c|}{ in progress } \\
\hline
\end{tabular}

ALTO = Adjuvant Lapatinib and/or Trastuzumab Treatment Optimization; NeoALTO = Neoadjuvant Lapatinib and/or Trastuzumab Treatment Optimization; NR = not reported; QOL = quality of life; SFI = survival free from illness; SFP = survival free from progression; CNS = central nervous system; TEACH = Tykerb Evaluation After Chemotherapy; IPT = illness progression time; GRR = general response rate; $\mathrm{EGF}=$ epidermal growth factor.

* general response, including full and partial response; ${ }^{\dagger} 16$ weeks of survival free from cancer progression; ${ }^{\ddagger} \mathrm{CNS}$ response/cerebral metastases response.

women with metastasized or advanced breast cancer with overexpression of HER-2 receptors and who had received first-line treatment with anthracycline, taxane and trastuzumab.

Lapatinib seems to be an adequate adjuvant treatment for HER-2positive breast cancer, since it demonstrates effectiveness in cases of advanced and metastasized cancer, appears to have few serious side effects and may be associated with reduction of the incidence of cerebral metastasis, in addition to its easy oral administration once a day.

Randomized clinical trials need to be implemented, with the objective of assessing the effectiveness of lapatinib as monotherapy for firstline or second-line treatment of advanced breast cancer, as well the effectiveness of lapatinib in associations as the primary treatment. An economic study with a cost effectiveness evaluation is also necessary, in order to incorporate this new technology into clinical practice.

\section{REFERENCES}

1. Parkin DM, Bray Fl, Devesa SS. Cancer burden in the year 2000. The global picture. Eur J Cancer. 2001;37(Suppl 8):S4-66.

2. Carrick S, Parker S, Thornton CE, Ghersi D, Simes J, Wilcken N. Single agent versus combination chemotherapy for metastatic breast cancer. Cochrane Database Syst Rev. 2009;(2):CD003372.

3. New and Emerging Technology Briefing. National Horizon Scanning Centre. Lapatinib (GW572016) for advanced or metastatic breast cancer. The University of Birmingham 2005. Available from: http://www.haps.bham.ac.uk/publichealth/horizon/outputs/ documents/2005/Lapatinib.pdf. Accessed in 2009 (Oct 28).

4. National Institute for Clinical Excellence. Guidance on the use of trastuzumab for the treatment of advanced breast cancer. London: National Institute for Clinical Excellence; 2002. Available from: http://www.nice.org.uk/nicemedia/pdf/advancedbreastcancerno34PDF. pdf. Accessed in 2009 (Oct 28).

5. Stockler M, Wilcken NR, Ghersi D, Simes RJ. Systematic reviews of chemotherapy and endocrine therapy in metastatic breast cancer. Cancer Treat Rev. 2000;26(3): 151-68. 
6. Moy B, Goss PE. Lapatinib: current status and future directions in breast cancer. Oncologist. 2006;11(10):1047-57.

7. Johnston S, Stebbing J. Breast cancer: metastatic in clinical evidence, issue 8. London: BMJ Publishing Group; 2002.

8. Wilcken N, Hornbuckle J, Ghersi D. Chemotherapy alone versus endocrine therapy alone for metastatic breast cancer. Cochrane Database Syst Rev. 2003;(2):cd002747.

9. Hortobagyi GN, Piccart-Gebhart MJ. Current management of advanced breast cancer. Semin Oncol. 1996;23(5 Suppl 11):1-5.

10. National Horizon Scanning Centre. New and Emerging Technology Briefing. Lapatinib (GW572016) for advanced or metastatic breast cancer. Available from: http://www.nelm. nhs.uk/en/NeLM-Area/Evidence/Drug-Specific-Reviews/496451/?query=GW572016\&r ank=100. Accessed in 2009 (Oct 28).

11. National Institute for Clinical Excellence. Guidance on the use of capecitabine for the treatment of locally advanced or metastatic breast cancer. Technology Appraisal Available from: http://guidance.nice.org.uk/TA62. Accessed in 2009 (Nov12).

12. National Institute for Clinical Excellence. Guidance on the use of vinorelbine for the treatment of advanced breast cancer. London: National Institute for Clinical Excellence; 2002. Available from: http://www.burypct.nhs.uk/cg/nicepdf/niceta54.pdf. Accessed in 2009 (Oct 28)

13. National Institute for Clinical Excellence. Taxanes for the treatment of breast cancer. NICE Technology Appraisal Guidance. Available from: http://www.nice.org.uk/cat.asp?c=1122. Accessed in 2009 (Nov 12).

14. National Institute for Health and Clinical Excellence. Gemcitabine for the treatment of metastatic breast cancer. London: National Institute for Health and Clinical Excellence 2007. Available from: http://www.nice.org.uk/nicemedia/pdf/TA116guidance.doc. Accessed in 2009 (0ct 28).

15. Slamon DJ, Clark GM, Wong SG, Levin WJ, Ullrich A, McGuire WL. Human breast cancer: correlation of relapse and survival with amplification of the HER2/neu oncogene. Science. 1987;235(4785):177-82

16. Geyer CE, Forster J, Lindquist D, et al. Lapatinib plus capecitabine for HER2-positive advanced breast cancer. N Engl J Med. 2006;355(26):2733-43.

17. Atalay G, Cardoso F, Awada A, Piccart MJ. Novel therapeutic strategies targeting the epidermal growth factor receptor (EGFR) family and its downstream effectors in breast cancer. Ann Oncol. 2003;14(9):1346-63.

18. Chu I, Blackwell K, Chen S, Slingerland J. The dual ErbB1/ErbB2 inhibitor, lapatinib (GW572016), cooperates with tamoxifen to inhibit both cell proliferation- and estrogen-dependent gene expression in antiestrogen-resistant breast cancer. Cancer Res. 2005;65(1):18-25.

19. Yarden $Y$. The EGFR family and its ligands in human cancer: signalling mechanisms and therapeutic opportunities. Eur J Cancer. 2000;37(Suppl 4):S3-8.

20. Rini BI. VEGF-targeted therapy in metastatic renal cell carcinoma. Oncologist. 2005;10(3): 191-7.

21. Yarden Y, Sliwkowski MX. Untangling the ErbB signalling network. Nat Rev Mol Cell Biol. 2001;2(2):127-37.

22. Mendelsohn J, Baselga J. Status of epidermal growth factor receptor antagonists in the biology and treatment of cancer. J Clin Oncol. 2003;21(14):2787-99.

23. Rusnak DW, Affleck K, Cockerill SG, et al. The characterization of novel, dual ErbB-2/ EGFR, tyrosine kinase inhibitors: potential therapy for cancer. Cancer Res. 2001;61(19): 7196-203.

24. Xia W, Liu LH, Ho P, Spector NL. Truncated ErbB2 receptor (p95ErbB2) is regulated by heregulin through heterodimer formation with ErbB3 yet remains sensitive to the dual EGFR/ ErbB2 kinase inhibitor GW572016. Oncogene. 2004;23(3):646-53.

25. Sáez R, Molina MA, Ramsey EE, et al. p95HER-2 predicts worse outcome in patients with HER-2-positive breast cancer. Clin Cancer Res. 2006;12(2):424-31.

26. Tripathy D, Slamon DJ, Cobleigh M, et al. Safety of treatment of metastatic breast cancer with trastuzumab beyond disease progression. J Clin Oncol. 2004;22(6):1063-70.

27. Montemurro F, Donadio M, Clavarezza M, et al. Outcome of patients with HER2-positive advanced breast cancer progressing during trastuzumab-based therapy. Oncologist. 2006;11(4): 318-24.

28. Slamon DJ, Leyland-Jones B, Shak S, et al. Use of chemotherapy plus a monoclonal antibody against HER2 for metastatic breast cancer that overexpresses HER2. N Engl J Med. 2001;344(11):783-92

29. Vogel CL, Cobleigh MA, Tripathy D, et al. Efficacy and safety of trastuzumab as a single agent in first-line treatment of HER2-overexpressing metastatic breast cancer. J Clin Oncol. 2002;20(3):719-26.

30. Drugs for breast cancer. Treat Guidel Med Lett. 2005;3(29):1-6.

31. Jadad AR, Moore RA, Carroll D, et al. Assessing the quality of reports of randomized clinical trials: is blinding necessary? Control Clin Trials. 1996;17(1):1-12.

32. Higgins JPT, Green S, editors. Cochrane Handbook for Systematic Reviews of Interventions 4.2.6 [updated September 2006]. In: The Cochrane Library, Issue 4. Chichester: John
Wiley \& Sons Ltd; 2006. Available from: http://www.cochrane.org/resources/handbook/ Handbook4.2.6Sep2006.pdf. Accessed in 2009 (Oct 27).

33. Geyer CE, Forster JK, Cameron D, et al. Scientific Special Session: Lapatinib in Trastuzumab Resistant Breast Cancer. In $42^{\text {nd }}$ Annual Meeting of the American Society of Clinical Oncology. June 2-6, 2006 Atlanta. Available from: http://www.asco.org/ASCOv2/Meetings/Abstracts?\&vmview=abst_detail_view\&conflD=40\&abstractID=90002. Accessed in 2009 (Nov 16).

34. Cameron D, Casey M, Press M, et al. A phase III randomized comparison of lapatinib plus capecitabine versus capecitabine alone in women with advanced breast cancer that has progressed on trastuzumab: updated efficacy and biomarker analyses. Breast Cancer Res Treat. 2008;112(3):533-43.

35. Phillips B, Ball C, Sackett D, et al. Oxford Centre for Evidence-based Medicine Levels of Evidence (May 2001). Available from: http://www.cebm.net/index.aspx?o=1047. Accessed in 2009 (Nov 12).

36. Food and Drug Administration. FDA Approves Tykerb for Advanced Breast Cancer Patients. Available from: http://www.fda.gov/NewsEvents/Newsroom/PressAnnouncements/2007/ ucm108866.htm. Accessed in 2009 (Oct 28)

37. Gomez HL, Chavez MA, Doval DC, et al. A phase II, randomized trial using the small molecule tyrosine kinase inhibitor lapatinib as a first-line treatment in patients with FISH positive advanced or metastatic breast cancer. Journal of Clinical Oncology. 2005;23(16 Suppl 1). [abstract 3046]. Available from: http://www.cancer.net/ASCOv2/Meetings/ Abstracts? \&vmview=abst_detail_view\&conflD=34\&abstract $\mid \mathrm{D}=31998$. Accessed in 2009 (Oct 28).

38. ClinicalTrials.gov. Paclitaxel with/without GW572016 (lapatinib) as first line therapy for women with advanced or metastatic breast cancer. Available from: http://www.clinicaltrials gov/ct/show/NCT00075270? order=1. Accessed in 2009 (Oct 28).

39. ClinicalTrials.gov. ErbB2 over-expressing metastatic breast cancer study using paclitaxel, trastuzumab, and lapatinib. Available from: http://www.clinicaltrials.gov/ct/show/ NCT00272987. Accessed in 2009 (Oct 29)

40. ClinicalTrials.gov . Study comparing GW572016 and letrozole versus letrozole in subjects with advanced or metastatic breast cancer. Available from: http://www.clinicaltrials.gov/ct/ show/NCT00073528. Accessed in 2009 (Oct 29).

41. Paoletti P. SVP MDC oncology. Tikerb at ASCO 2006. Available from: http://www.gsk.com/investors/presentations/2006/06072006-roundtable-paole.pdf. Accessed in 2009 (Nov 12).

42. Blackwell KL, Kaplan EH, Franco SX, et al. A phase II, open-label, multicenter study of GW572016 in patients with trastuzumab-refractory metastatic breast cancer. Journal of Clinical Oncology. 2004;22(14 Suppl.):196. [abstract 3006]. Available from: http://meeting ascopubs.org/cgi/content/abstract/22/14_suppl/3006. Accessed in 2009 (Oct 29).

43. Blackwell KL, Burstein $\mathrm{H}$, Pegram $\mathrm{M}$, et al. Determining relevant biomarkers from tissue and serum that may predict response to single agent lapatinib in trastuzumab refractory metastatic breast cancer. Journal of Clinical Oncology. 2005;23(Suppl 16):S193. [abstract 3004]. Available from: http://meeting.ascopubs.org/cgi/content/abstract/23/16_suppl/ 3004 maxtoshow $=\& H I T S=20 \&$ hits $=20 \&$ RESULTFORMAT $=\&$ fulltext=Determining + relevant + biomarkers+from+tissue+and+serum+that+may+predict+response+to+single+agent+lapa tinib+in+trastuzumab+refractory+metastatic+breast+cancer+\&searchid=1\&FIRSTINDEX=0 \&resourcetype=HWCIT. Accessed in 2009 (Oct 29).

44. Burstein H, Storniolo AM, Franco S, et al. A phase II, open-label, multicenter study of lapatinib in two cohorts of patients with advanced or metastatic breast cancer who have progressed while receiving trastuzumab-containing regimens. Ann Oncol. 2004;15(Suppl 3):iii27 (abstract 1040). Available from: http://annonc.oxfordjournals.org/cgi/reprint/15/ suppl_3/iii27. Accessed in 2009 (Oct 29).

45. Lapatinib in combination with trastuzumab versus lapatinib monotherapy in subjects with metastatic breast cancer. ClinicalTrials.gov [Web site]. Available from: http://www.clinicaltrials.gov/ct/show/NCT00320385? order=1. Accessed in 2009 (Apr 16).

46. Lin NU, Dieras V, Paul D, et al. EGF105084, a phase II study of lapatinib for brain metastases in patients (pts) with HER2+ breast cancer following trastuzumab $(\mathrm{H})$ based systemic therapy and cranial radiotherapy (RT) [abstract]. Journal of Clinical Oncology. 2007;25(Suppl 18):S1012. Available from: http://meeting.ascopubs.org/cgi/content/abstract/25/18 suppl/1012. Accessed in 2009 (Oct 28).

47. Lin NU, Carey LA, Liu MC, et al. Phase II trial of lapatinib for brain metastases in patients with HER2+ breast cancer. Journal of Clinical Oncology. 2006;24(Suppl 18):S503. Available from: http://meeting.ascopubs.org/cgi/content/abstract/24/18_suppl/503?maxtoshow $=\&$ HITS $=20$ \&hits=20\&RESULTFORMAT $=$ \&fulltext=Phase+ll+trial+of+lapatinib+for+brain + metastases+in+patients+with+HER2_breast+cancer\&searchid=1\&FIRSTINDEX=0\&resourc etype=HWCIT. Accessed in 2009 (Oct 28)

48. Trudeau M, Johnston S, Kaufman, et al. Lapatinib (Tykerb ${ }^{\circ}$ ) monotherapy in patients (PTS) with recurrent inflammatory breast cancer (IBC): clinical activity and biologic predictors of response. Annals of Oncology. 2006;17(Supplement. 9):ix69. Available from: http:// annonc.oxfordjournals.org/cgi/reprint/17/suppl_9/ix69?ijkey=ef1d5135af012af5c4251 bfec1ac99e8573ec9f9\&keytype2=tf_ipsecsha. Accessed in 2009 (0ct 28). 
49. Cristofanilli M, Boussen $\mathrm{H}$, Baselga J, et al. A phase II combination study of lapatinib and paclitaxel as a neoadjuvant therapy in patients with newly diagnosed inflammatory breast cancer (IBC) [abstract]. Breast Cancer Research and Treatment. 2006;100(Suppl 1):S5.

50. Piccart-Gebhart MJ, Perez EA, Baselga J. ALTTO (adjuvant lapatinib and/or trastuzumab treatment optimization) study (BIG 2- 06/N063D/EGF106708): A phase III study for HER-2overexpressing early breast cancer [abstract]. The Breast. 2006;15(Suppl 1):S5.

51. Moy B, Maltzman JD, Goss PE. Phase II study of lapatinib after completion of adjuvant therapy in trastuzumab-naive women with ErbB2-overexpressing breast cancer. The Breast. 2007;16(Suppl 1):S47.

52. Moy B, Goss PE. TEACH: Tykerb evaluation after chemotherapy. Clin Breast Cancer. 2007;7(6):489-92.

53. ClinicalTrials.gov. Neo ALTTO (Neoadjuvant Lapatinib and/or Trastuzumab Treatment Optimization) Study. Available from: http://www.clinicaltrials.gov/ct2/show/NCT00553358?term $=$ lapatinib\&type $=$ Intr\&cond $=$ breast + cancer\&intr $=\% 22$ Paclitaxel\%22\&rank=15. Accessed in 2009 (0ct 29).
Source of funding: This study received financial support from GlaxoSmithKline Conflict of interest: None

Date of first submission: February 6, 2009

Last received: November 17, 2009

Accepted: November 18, 2009

Address for correspondence:

Rachel Riera

Centro Paulista de Economia da Saúde

Rua Botucatu, 685

Vila Clementino - São Paulo (SP) - Brazil

CEP 04023-062

E-mail: ecosaude2001@epm.br 